\title{
Pemilihan Sekolah Swasta Berbasis Agama dalam Perspektif Angst Society
}

\author{
Nurhadi \\ Pendidikan Sosiologi Antropologi Universitas Sebelas Maret, Surakarta \\ (e-mail: nurhadi@staff.uns.ac.id)
}

\begin{abstract}
There has been a sharp increase of the number of parents sending their children to religious-based private schools, ranging from early childhood education to that of high school, since the past three decades. In addition to the urban and peri-urban population, this trend has also been extending that of rural, in which individual decision making is presumed to be also strongly influenced by, or at least takes account seriously consideration made by, extended family. This research focuses on how parents come up with the decision to send their children to religious-based private school. Applying social network analysis, this research aims at understanding and explaining the process of socialization, dissemination, and the fortification of ideas on the importance of sending children to the religiousbased private school. The results of this research are: First, there is the certain dominant perception among parents that the community and society at-large in which parents and their families belong to pose threats to the growth of children and teenagers. Second, there are certain negative perceptions on public and non-religious-based schools. The teaching of religious, moral, and virtuous values are considered as insufficient.
\end{abstract}

Sejak tiga puluh tahun terakhir, sekolah swasta berbasis agama cenderung semakin banyak diminati mulai dari jenjang pendidikan usia ini dini sampai dengan menengah atas. Selain pada masyarakat urban dan semi-urban, kecenderungan ini juga mulai merambah perdesaan, wilayah yang identik dengan masih kuatnya keluarga dan kerabat dalam proses pengambilan keputusan individu. Penelitian ini memfokuskan perhatiannya kepada proses pengambilan keputusan orang tua dalam memilih sekolah swasta bebasis agama untuk anak-anak mereka. Analisis jaringan sosial digunakan untuk memahami proses penanaman, penyebaran, dan diperkuatnya gagasan tentang pentingnya menyekolahkan anak di sekolah swasta berbasis agama. Hasil yang diperoleh adalah bahwa menyekolahkan anak di sekolah berbasis agama banyak dipengaruhi oleh dua hal yang bertautan satu sama lain. Pertama, terdapat persepsi dominan yang memahami masyarakat sebagai salah satu bentuk ancaman bagi tumbuh-kembang anak-anak dan remaja. Kedua, persepsi negatif terhadap sekolah milik pemerintah dan sekolah swasta yang berbasis non-agama. Pendidikan agama, moral, dan budi pekerti di sekolah-sekolah tersebut dipandang tidak memadai.

Keywords: decision-making process; dualistic families; perception of the external threat, religious capital; social network 


\section{Pendahuluan}

Kecenderungan semakin diminatinya sekolah swasta merupakan fenomena yang bersifat global. Sejumlah studi di beberapa negara menunjukkan indikasi tersebut. Data tahun 2009 menunjukkan bahwa: (1) 31\% dari 1,99 juta siswa sekolah dasar menjadi murid di sekolah swasta; dan (2) 33\% dari total 2,23 juta siswa sekolah menengah bersekolah di sekolah swasta (Jacob dan Ma 2013). Di Amerika Serikat, US Department of Education melaporkan pada tahun 2010 bahwa dari 98.800 sekolah dasar dan menengah di Amerika, 28.000 di antaranya adalah sekolah swasta. Dari tahun 1993 sampai dengan 2007, peserta didik di sekolah negeri meningkat antara 11-16\%; sekolah swasta berbasis agama meningkat antara 8-9\%; dan sekolah sekuler naik antara 2 sampai 3\% (Vellos 2013). Studi di Meksiko menunjukkan sekolah swasta secara singnifikan menaikkan angka partisipasi sekolah dan memperluas akses pendidikan (Binelli dan Rubio-Codina 2013).

Data Kementerian Pendidikan dan Kebudayaan (Kemendikbud) Republik Indonesia menunjukkan tingginya kontribusi sekolah swasta bagi perluasan akses terhadap pendidikan mulai dari jenjang pendidikan usia dini sampai dengan tingkat menengah atas (lihat Diagram 1). Sampai dengan tahun 2015, tercatat Jumlah Taman Kanak-Kanak dan SMA swasta jauh melampui sekolah negeri pada jenjang yang sama (lihat Diagram 1). Data tersebut ditegaskan oleh Asadullah dalam penelitian tentang peningkatan kecenderungan bersekolah di lembaga pendidikan swasta di Indonesia antara tahun 2009 sampai dengan 2016. Dua jenjang terbawah, yaitu pendidikan usia dini (PAUD) dan Sekolah Dasar (SD) menjadi penyumbang peningkatan terbesar. Data Kemendikbud menunjukkan, pada tingkat nasional, di tengah-tengah jumlah SD negeri mulai dari tahun 2009 sampai dengan 2016 yaitu sebesar $0.41 \%$, jumlah SD swasta justru mengalami peningkatan sebesar 25.91\% (Asadullah 2018).

Sekolah swasta ditempatkan pada kerangka kebijakan yang sama dengan sekolah negeri, sekalipun ada celah untuk memasukkan keunggulan tertentu yang biasanya dipengaruhi oleh faktor penciri yang menjadi identitas khas lembaga. Penonjolan nilai le bih tersebut umumnya berkorelasi dengan standar pembiayaan. Tidak ada ketentuan yang secara eksplisit mengatur besaran maksimal sumbangan masyarakat dan orang tua terhadap pembiayaan di sekolah swasta.

Pendidikan swasta masuk ke dalam sistem pasar. Ia menjadi komoditas yang nilainya ditentukan oleh variabel penawaran dan permintaan. Kemampuan untuk memilih produk pendidikan swasta sepenuhnya dipengaruhi kekuatan modal finansial yang mampu diakses oleh masing-masing orang tua. Sektor swasta dapat dioptimalkan untuk mengisi kesenjangan antara peningkatan kebutuhan terhadap sekolah dengan keterbatasan anggaran pendidikan negara. Di samping itu, sekolah swasta dipandang lebih mampu menjalankan manajemen secara efisien. Tekanan birokasi yang seringkali menjadi kendala peningkatan mutu sekolah dapat diminimalisasi. Mereka dapat 


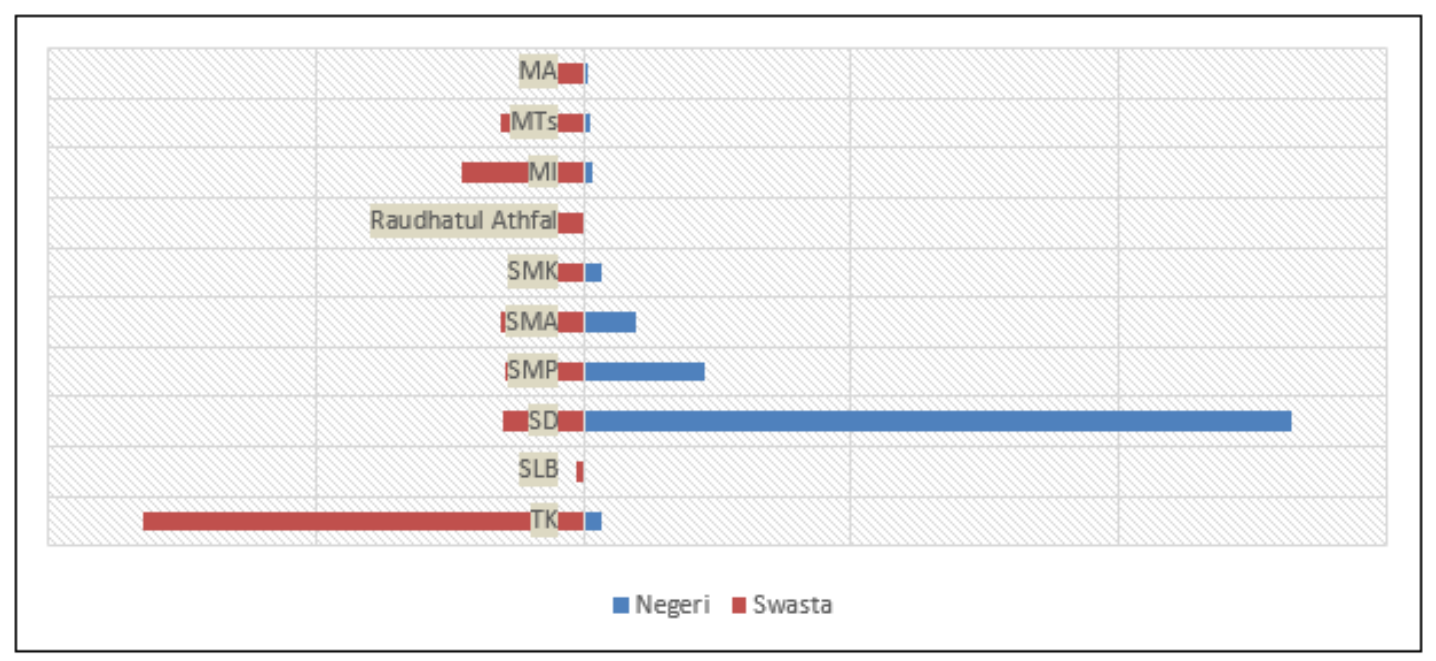

Diagram 1

Perbandingan Jumlah Sekolah Negeri : Swasta

Sumber: Kemendikbud (2016)

secara lebih leluasa menarik dana pendidikan dari orang tua, karena beragamnya keunggulan yang ditawarkan (misalnya, digunakannya bahasa asing dalam proses belajar mengajar; pembelajaran yang terfokus pada potensi individu siswa, penerapan metode pengajaran mutakhir yang dianggap sukses dijalankan di negara-negara lain, penggunaan teknologi modern dalam pendidikan dan pengajaran; kuatnya pengajaran agama dan pendidikan karakter, dan lain sebagainya).

Di Australia, sejak tiga puluh tahun silam telah muncul gagasan bahwa pendidikan sebagai sebuah investasi. Dua puluh lima persen orang tua di negeri tersebut memilih untuk menyekolahkan anaknya di sekolah swasta berbayar daripada sekolah negeri yang bebas biaya. Mereka memperhitungkan bahwa ada keuntungan yang terutama bersifat nonmaterial dari investasi tersebut (Williams dan
Carpenter 1991). Hal serupa terjadi di Monrovia, Liberia, yang menunjukkan bahwa sekolah swasta lebih diminati daripada sekolah negeri (Longfield dan Tooley 2017). Di Malaysia, alasan utama yang menjadi pertimbangan orang tua untuk memasukkan anaknya ke sekolah swasta adalah silabus sekolah, baru disusul oleh lingkungan sekolah, dan fasilitas yang disediakan. Prestasi sekolah hanya menduduki prioritas ke empat (Yaacob, Osman, dan Bachok 2014).

Di Polandia, ideologi pasar banyak memengaruhi strukturasi dan restruktruasi pendidikan. Hal ini mulai terjadi sejak tumbangnya komunisme pada akhir dasawarsa 1990-an. Pasar menjadi alat yang sangat efektif untuk mencapai tujuan-tujuan sekolah swasta, yaitu terwujudnya model pendidikan yang memberikan lebih banyak kebebasan ketimbang peningkatan disiplin dan pekerjaan rumah 
bagi peserta didik; minimalisasi kontrol terhadap guru dan siswa; penghapusan persyaratan pembelajaran dan pengawasan yang terlalu ketat; diperluasnya cakrawala wawasan siswa; perhatian yang lebih kepada keunikan siswa; berkurangnya kompetisi dan stress; lebih besarnya semangat kerjasama dan iklim saling dukung antar pihak di dalam sistem pendidikan; ruang kelas yang lebih "hidup"; dan pembebasan kepada siswa untuk menentukan cita-cita yang ingin diraihnya. Halhal tersebut bertolak belakang dengan sekolah negeri yang disamping mengabaikan pilihan dan aspirasi orang tua, juga digambarkan sebagai keras, sarat akan hukuman, mengesampingkan bakat dan keunikan peserta didik, terlalu tersentralisasi, hirarkis, dan tidak manusiawi.

Dikatakan bahwa pendidikan di Polandia pasca Perang Dunia II tersubordinasi oleh ideologi dan politik yang melahirkan generasi yang berkarakter seragam, cenderung bersikap konformis, pasif, dan apolitis. Di samping dorongan semangat perlawanan terhadap sistem pendidikan lama, banyak diminatinya sekolah-sekolah swasta di Polandia oleh masyarakat terkait erat dengan kuatnya ikatan antar orang tua dan komitmen serta pengabdian guru yang didorong oleh semangat altruistik (Heyns 1996). Di Selandia Baru, jarak rumah ke sekolah menjadi salah satu faktor terpenting dalam memilih sekolah (Mandic et al. 2017).

Berlakunya ideologi pasar dalam pendidikan berdampak pada semakin timpangnya akses terhadap pendidikan dan efek praktik persekolahan juga diulas dalam konteks masyarakat Denmark (Sorensen 1996). Ketimpangan akses terhadap pilihan model persekolahan banyak dipengaruhi oleh latar belakang sosial ekonomi siswa. Mereka yang berasal dari kalangan berada memperoleh lebih banyak keuntungan karena dapat menetapkan preferensi terhadap jenis sekolah swasta yang mengadopsi filosofi pendidikan tertentu, misalnya Montessori, Reggio Emilia, atau Waldroff. Sementara itu, mereka yang memilih menyekolahkan anaknya di sekolah negeri dapat membeli fasilitas tambahan penunjang prestasi belajar dalam bentuk pelajaran tambahan, guru privat, dan sejumlah perangkat yang akan memudahkan mereka memahami dan menyelesaikan soal-soal ujian (Ainsworth 2013). Di banyak negara, sekolah swasta berafiliasi kepada organisasi keagamaan. Di samping sebagai penyandang dana, organisasi yang memayunginya menyediakan platform ideologis dan seperangkat metode pencapaian misi melalui jalur pendidikan (Vellos 2013).

Dampak lain adalah terjadinya "marketisasi pendidikan”. Di Shady Hills California, Amerika Serikat, berlangsung perdebatan panjang tentang peran dan posisi orang tua dalam kaitan dengan sekolah. Menempatkan diri sebagai "pelanggan" sekolah, dengan menggunakan pelbagai kosa kata neo-liberal, sekelompok orang tua menuntut hak untuk dapat memilih materi kurikulum dan metode pengajaran (Rosen 2003). Data survei dikumpulkan dari sampel orang tua di wilayah metropolitan Bilbao, Spanyol untuk menyusun estimasi model pilihan gabungan. Data tersebut berisi pilihan sekolah yang awalnya diminati dan 
data sekolah yang akhirnya dipilih untuk anakanak mereka. Temuan pertama penelitian ini adalah bahwa preferensi suami dan istri dalam kaitan dengan pilihan sekolah tidak jauh berbeda. Ke dua, preferensi dipengaruhi oleh karakteristik sekolah. Temuan terakhir adalah bahwa pengambilan keputusan terkait dengan pemillihan sekolah bukan merupakan hasil negosiasi yang berlangsung secara setara. Merujuk kepada penelitian lain, terdapat kecenderungan peran dominan istri dalam memilih sekolah untuk-anak mereka (Mariel, Scarpa, dan Vega-bayo 2018).

Dalam studi tentang perbandingan minat bersekolah di Indonesia, dikatakan bahwa faktor yang paling menentukan dalam pemilihan jenis sekolah (negeri, swasta, atau madrasah) adalah sosio-ekonomi. Kalangan masyarakat urban yang lebih terdidik dan lebih makmur cenderung menyekolahkan anaknya di sekolah negeri dan swasta nonkeagamaan. Keluarga perdesaan yang lebih miskin dan kurang terdidik cenderung menyekolahkan anak-anaknya, terutama anak perempuan, ke madrasah (Asadullah 2018).

Kecenderungan umum yang dapat ditelaah dari penelitian-penelitian tersebut adalah diletakkannya individu pada posisi sentral dalam pengambilan keputusan. Ada pengabaian terhadap fakta bahwa diambilnya keputusan adalah implikasi dari nilai-nilai dan norma yang dianut oleh individu. Nilai dan norma berada pada aras sosial. Dengan demikian diperlukan perspektif baru yang lebih menekankan peran kelompok dalam penetapan pilihan individu, yang dalam kasus ini adalah orang tua siswa. Penelitian ini hendak men- jawab pertanyaan tentang proses pengambilan keputusan keluarga dalam pemilihan sekolah untuk anak-anak mereka.

Selain itu, teori pilihan rasional merupakan salah satu sudut pandang yang banyak digunakan studi pemilihan sekolah. Konsep utama dalam teori pilihan rasional adalah optimasi. Secara garis besar, konsep ini bermakna bahwa keputusan yang diambil seseorang didasari oleh keinginan untuk meminimalisasi kerugian pada satu sisi, dan mengoptimalkan keuntungan atau manfaat pada sisi yang lain. Lebih lanjut, teori ini menjelaskan tentang bagaimana pelbagai tindakan aktor tersebut saling bertaut sehingga menghasilkan imbas secara sosial (Coleman dan Fararo 1992). Dijadikannya maksimalisasi keuntungan dan minimalisasi kerugian menjadi salah satu kelemahan dari teori ini. Seolah-olah ekonomi menjadi motif yang mendominasi motif-motif yang lain. Selain melihat peran kelompk dan penentuan pilihan individu, alternatif yang ditawarkan oleh tulisan ini adalah perspektif "angst society". Secara harfiah, konsep ini bermakna "masyarakat yang dilanda rasa takut". Menggugat perspektif Ulrich Beck, alih-alih masyarakat risiko, yang justru lahir dari era modernisme lanjut adalah dominannya rasa takut akan pelbagai ancaman eksternal (Scott 2000). Munculnya konsep ini terinspirasi oleh gagasan Douglas (1992) tentang kaitan erat antara individualisme (individualism), risiko (risk), dan tindakan menyalahkan (blame). Risiko direspons secara berbeda oleh masing-masing anggota masyarakat. Tidak memadainya mekanisme pengurangan dan penanggulangan risiko yang 
dikembangkan oleh negara mendorong setiap orang mengembangkan metode, mekanisme, cara, dan taktik secara mandiri agar terhindar dari risiko. Contoh yang paling kentara pada kasus wilayah-wilayah peri-urban Indonesia adalah maraknya pembangunan dinding dan pagar rumah dan semakin intensifnya pemakaian kamera pengawas pada skala rumah tangga dan unit permukiman.

Meningkatnya individualisasi risiko beriringan dengan strategi menyalahkan (blame strategy). Pada level kolektif, berlangsung pengkambinghitaman terhadap kelompok-kelompok yang telah berada pada situasi rentan dan marjinal, baik secara ekonomi maupun sosial. Di antara kelompok yang dipersepsikan membawa masalah sosial dan dampak buruk bagi anggota masyarakat lain tersebut adalah kelompok miskin, pengangguran, kaum homoseksual, kelompok yang tidak taat beribadah formal, anak-anak putus sekolah, orang asing, dan kelompok-kelompok lain yang secara garis besar diberi label sebagai liyan (others). Sistem proteksi dibuat dengan mengembangkan pola pemilahan antara "kita" dengan "mereka". "Kita" mewakili kelompok "normal" dan mapan. Umumnya kelompok ini secara subjektif menempatkan diri pada level menengah bawah (lower-middle-group) sampai dengan menengah atas (higher middle-group). "Mereka" dipandang sebagai representasi kelas bawah. Pada level individu, terjadi konsumsi massif terhadap sejumlah sistem, perangkat, dan teknologi yang diyakini dapat mencegah, mengurangi, atau menanggulangi risiko (Douglas 1992). Pada skala yang lebih luas, kedua strategi tersebut saling melengkapi. Pada gilirannya, berkembang rasa takut kolektif yang menjadi bibit bagi tumbuhnya angst society.

Penelitian ini menggunakan metode penelitian kualitatif. Berangkat dari tesis bahwa tindakan manusia adalah hasil olah pikir, keputusan atas suatu pilihan merupakan luaran dari proses yang melibatkan dua faktor, yaitu narasi dan relasi kuasa (Rapley 2014). Data yang dikumpulkan adalah data kognitif. Sebanyak 60 orang tua siswa yang tinggal di Kota Surakarta dan kabupaten-kabupaten yang berbatasan dengannya, yaitu Karanganyar, Sukoharjo, dan Boyolali dipilih untuk diwawancarai. Dari masing-masing kabupaten atau kota dipilih 15 orang tua siswa yang menyekolahkan anaknya di sekolah swasta Islam. Informan dipilih menggunakan teknik stratified purposive sampling. Langkah ke dua adalah menentukan kategori informan berdasarkan perbedaan karakteristik spasial, yaitu perkotaan (urban), pinggir kota (periurban), dan perdesaan (rural). Dari masingmasing karakteristik spasial diambil informan yang mewakili jenis pekerjaan, yaitu pegawai negeri, wirausaha, dan karyawan swasta. Dari masing-masing jenis pekerjaan diambil 5 orang, sehingga total responden yang diwawancarai adalah 45 orang. Wawancara dilakukan dengan menghadirkan ayah dan ibu siswa. Hal ini dimaksudkan untuk meningkatkan derajat reliabilitas dan validitas data. Kedua belah pihak dapat saling melakukan pengecekan dan Kehadiran ayah dan ibu dalam wawancara juga meminimalisasi bias gender dalam dalam pengumpulan data. 
Langkah selanjutnya adalah pemilahan dan interptetasi data. Pemilahan data dimaksudkan untuk memisahkan data-data yang relevan dengan pertanyaan penelitian dengan yang tidak. Interpretasi dilakukan dengan melihat keterkaitan antara satu pernyataan dengan pernyataan lain memaknainya dengan merujuk kepada konteks latar belakang budaya informan. Wawancara dilakukan dalam bahasa Indonesia, namun ada sejumlah terminologi dalam bahasa lokal, terutama bahasa Jawa dan sedikit bahasa Arab, yang juga diungkapkan oleh informan. Mereka berpandangan bahwa terminologi-terminologi tersebut sulit untuk mereka cari padanannya dalam bahasa Indonesia. Dengan latar belakang kultural dan berbicara dengan bahasa ibu yang sama dengan informan, peneliti berupaya melakukan interptetasi atas pernyataan-pertanyaan tersebut (Willig 2014). Selain data berupa hasil wawancara, peneliti juga melakukan telaah terhadap isi berita di media massa. Hal ini dimaksudkan untuk menemukan sejumlah benang merah antara pemahaman informan terhadap agama dan pendidikan anak dengan wacana yang disebarluaskan melalui media (Hodgetts dan Chamberlain 2014).

\section{Pendidikan Formal sebagai Expert System (Sistem Ahli)}

Masyarakat modern mengembangkan mekanisme untuk menaikkan peluang keberhasilan dan meminimalisasi potensi kegagalan, yang oleh Anthrony Giddens disebut sebagai sistem ahli (expert system) (Giddens 1990). Satu hal yang melekat dalam sistem ahli adalah konsep rasa aman ontologis. Ini digambarkan sebagai situasi ketika individu merasa aman manakala berhubungan dengan dan memanfaatkan sistem yang sekalipun cara kerjanya tidak benar-benar ia pahami. Sebagai contoh, penumpang pesawat sama sekali tidak mengerti bagaimana mekanisme navigasi, cara kerja mesin jet, dan teknik pendaratan, namun mereka percaya dan yakin bahwa wahana yang mereka tumpangi bekerja dengan baik dan akan membawa mereka selamat sampai kepada tujuan. Pendidikan formal adalah salah satu contoh dan ilustrasi sempurna atas beroperasinya sistem ahli dan terciptanya rasa aman ontologis dalam masyarakat modern.

Salah satunya adalah pendidikan formal. Sebagai sebuah sistem, pendidikan formal menyediakan perangkat keras (teknologi pembelajaran dan pengajar) dan perangkat lunak (kurikulum dan teknik pembelajaran) bagi pengembangan potensi dan kompetensi diri peserta didik. Di samping itu, pendidikan menyediakan rasa aman dari ketakutan terhadap ketidakpastian kehidupan di masa depan Secara simplistik, kekhawatiran terhadap buruknya kondisi ekonomi pribadi dan keluarga diantisipasi dengan membangun kompetensi dan daya saing dalam memperebutkan lapangan pekerjaan. Kekhawatiran akan jatuhnya martabat akibat rendahnya posisi dalam stratifikasi sosial diantisipasi oleh lembaga pendidikan dengan memberikan pengakuan ketercapaian dalam menempuh pelatihan formal sampai pada jenjang tertentu. Hal ini diyakini akan membuka lebar peluang bagi mobilitas ekonomi dan sosial secara vertikal. Masyarakat pada umumnya tidak memahami bagaimana kurikulum disusun, bagaimana teknik pembelajaran menurut 
jenjang usia diberlakukan, bagaimana bimbingan konseling dilakukan, dan hal-hal lain yang menyangkut cara kerja sistem pendidikan formal. Di tengah-tengah ketidaktahuan tersebut, mereka meyakini pendidikan formal adalah solusi terbaik untuk persiapan menuju kehidupan dewasa anak-anak mereka.

\section{Keluarga Dualistis}

Secara tradisional, keluarga tidak ditempatkan pada posisi dikotomis dengan masyarakat di Indonesia. Keduanya adalah cermin satu sama lain serta menjadi gambaran ideal masing-masing. Masyarakat dijalankan dengan kaidah-kaidah, prinsip, dan cara kerja sebagaimana keluarga. Peran-peran simbolik yang mewakili sosok orang tua dan anak lengkap dengan atribut serta tanggung jawab yang melekat pada keduanya berlaku pada masyarakat. Keluarga pun demikian. Peran ayah identik dengan peran pemimpin formal di tengah-tengah masyarakat (Sciortino dan Smyth 2002).

Kini, keluarga Indonesia semakin menunjukkan kecenderungan ke arah karakter dualistik. Masyarakat mengalami transisi, yaitu mulai ditinggalkannya sebagian nilai-nilai dan norma tradisional, pada satu sisi, dan semakin besarnya pengaruh cara hidup modern. Pada masyarakat modern, ideologi berkeluarga yang paling banyak memperoleh pengakuan dan dijalankan pada tataran praksis adalah ideologi keluarga konjugal. Ideologi ini menyebarkan nilai-nilai kebebasan individu dalam menentukan berbagai pilihan hidup, misalnya menyangkut pilihan jodoh, pilihan menetap pasca menikah, pilihan jumlah anak yang ingin dimiliki, bekerja dan tidaknya istri setelah menikah, dan lain sebagainya (Tangdilintin 2004).

Kehidupan berkeluarga bergerak pada jalur yang diawali dengan ikrar pernikahan dan diakhiri dengan putusnya hubungan antara suami dengan istri, baik karena perceraian atau kematian. Di antara dua ujung tersebut terdapat fase krusial, yaitu mengasuh anak, yang diawali dengan melahirkan anak dan, pada sebagian masyarakat, berakhir manakala sang anak menikah. Upacara ritual perkawinan masyarakat Jawa, misalnya, sarat akan simbol yang dimaknai sebagai 1) dilepaskannya tanggung jawab mengasuh anak perempuan dari orang tua kepada menantu laki-laki; dan 2) diberikannya kepercayaan anak lakilaki untuk mengelola rumah tangga baru.

Pola pengasuhan pada masyarakat Indonesia identik dengan pembagian peran domestikpublik. Ayah bertanggungjawab mencari nafkah. Ibu bertanggungjawab mengurus rumah tangga. Termasuk dalam urusan rumah tangga adalah mengasuh anak. Tidak sekedar menyusui, seorang ibu juga dituntut untuk memiliki kompetensi tertentu untuk mempersiapkan anak menuju ke fase dewasa. Ibu dibebani dengan tugas ganda yaitu menjadi pelaksana diturunkannya "visi dan misi" keluarga kepada anak sekaligus mengajarkan nilai dan norma yang berlaku di dalam masyarakat.

Setiap pasangan suami istri menetapkan target-target yang dianggap mencerminkan keberhasilan dalam kehidupan berkeluarga, 
yang dilihat menurut indikator ekonomi, status sosial, dan kebanggan diri sebagai individu, pasangan, maupun keluarga. Berbeda dengan dua indikator lain yang cenderung bersifat kuantitatif-empirik, indikator kebanggaan diri bersifat kualitatif-subjektif-hermeneutis. Tidak ada ukuran yang bersifat tunggal dan dapat diberlakukan pada semua keluarga. Setiap individu, pasangan, atau keluarga menetapkan secara sepihak ukuran tersebut. Mereka selanjutnya menarasikan tercapainya target tersebut kepada pihak lain dalam rangka mengejar pengakuan mereka yang berada di dalam jangkauan jejaring sosialnya. Setelah pengakuan diraih, maka ada semacam tantangan untuk semakin menaikkan batas atas dan mencari pengakuan baru dari jejaring sosial yang lebih luas atau dari mereka yang menduduki strata sosial yang lebih tinggi.

Salah satu aspek penting kebanggan diri dalam kehidupan berkeluarga adalah anak. Sejak dari kelahirannya, anak digambarkan sebagai sosok yang dinantikan kehadirannya, dijadikan sebagai objek kasih sayang, dijadikan sebagai alasan utama untuk senantiasa ingat rumah, dan berbagai ekspresi lain yang menunjukkan besarnya perhatian orang tua. Ritus pasca kelahiran sarat dengan unsur religius, misalnya bisikan adzan dan iqamah di dekat telinga bayi yang baru lahir; ritual memberi nama dengan menyembelih kambing/domba; atau lantunan shalawat nabi dalam ritual memotong rambut. Ada pesan kuat tentang dipentingkannya sisi keagamaan dalam pengasuhan anak. Orang tua memanjatkan do'a dan menyatakan harapan. Berbeda dengan do'a yang cenderung bersifat normatif dan lebih bernuasa sakral, harapan cenderung lebih konkret dengan muatan yang bersifat imanen, misalnya menyangkut capaian belajar, profesi yang dicita-citakan, dan pasangan yang didambakan.

Di balik keinginan untuk mengejar target dan pengakuan muncul rasa khawatir akan kegagalan. Pada akhirnya kehidupan rumah tangga bergerak di antara pendulum keberhasilan dan kegagalan semacam itu. Di antara hal yang terkait dengan mengasuh anak dan beban visi dan misi yang diusung keluarga, memilih pendidikan formal adalah yang paling pelik. Sejumlah pertimbangan dimasukkan sebagai variabel pengampilan keputusan, antara lain kemampuan pembiayaan, jarak sekolahrumah, reputasi sekolah, dan jenis sekolah (negeri/swasta, berbasis agama/tidak berbasis agama). Banyak sedikitnya pilihan yang tersedia banyak dipengaruhi oleh kemampuan finansial orang tua untuk membiayai sekolah anaknya. Sekolah swasta yang dimiliki oleh yayasan atau perkumpulan yang dibentuk berdasarkan atas identitas agama banyak dipilih orang tua di kota Solo dan kabupatenkabupaten yang berbatasan dengan kota ini, yaitu Boyolali, Sukoharjo, dan Karanganyar.

Meningkatnya kesempatan kerja dan tumbuhnya kesadaran akan pentingya perempuan menurunkan tingkat ketergantungan secara sosial dan ekonomi terhadap pasangan semakin memotivasi kaum perempuan untuk semakin berani menetapkan pilihan menjalankan aktivitas di sektor publik. Hal ini berpotensi menurunnya kuantitas "curahan kasih sayang" yang diberikan ibu kepada anaknya. Berbeda dengan masyarakat agraris yang memahami 
anak sebagai asset berharga bagi keluarga, kini anak cenderung dipandang sebagai beban yang secara pembiayaan memberatkan keuangan keluarga. Orang tua menyerahkan sebagian tugas mengasuh dan mendidik anak kepada pihak luar. Hal tersebut ditangkap sebagai peluang bisnis oleh lembaga pendidikan formal swasta. Terjadi perluasan sistem alih daya (outsourcing), dari urusan-urusan yang bersifat publik dan berorientasi kepada laba ke sektor domestik yang bersifat nir-laba. Pendidikan anak pada gilirannya dilihat dan dijalankan dengan logika laba-rugi. Sebagai sebuah investasi, kesuksesan pendidikan anak diukur berdasarkan prestasi belajar yang diyakini akan berkorelasi positif dengan keberhasilan anak dalam memperoleh pekerjaan kerah putih dan karir yang cemerlang.

\section{Persepsi Negatif tentang Masyarakat}

Keputusan untuk menyekolahkan anak di sekolah swasta berbasis agama dilandasi atas pertimbangan yang muncul akibat rasa khawatir terhadap pengaruh negatif dari teknologi informasi, media hiburan, dan lingkungan tempat tinggal kepada perkembangan psikologis anak. Pertama, teknologi informasi dipersepsikan sebagai penuh dengan muatan yang tidak mendidik, antara lain pornografi, berita palsu, kekerasan, permainan daring (online game), perjudian, dan sejumlah muatan lain yang orang tua merasa tidak sanggup menyaring dan mengendalikan penggunaannya. Orang tua menempatkan diri pada posisi inferior di hadapan teknologi informasi. Mereka merasa tidak sanggup mengejar ketertinggalan dalam memahami dan menguasai cara kerja teknologi ini, karena selalu muncul perbaruan sistem dan aplikasi dalam kurun waktu yang terlalu pendek untuk dipelajari. Kedua, kendati cenderung mengalami penurunan minat, televisi masih dipandang sebagai membahayakan psikologi anak. Banyak tayangan yang tidak cocok untuk anak-anak. Pemberian rating untuk menandai kelayakan tayang berdasarkan atas usia yang dilakukan oleh stasiun televisi dianggap tidak memadai. Ketiga, masyarakat yang dicitrakan sebagai sarat akan penyakit sosial. Alam berpikir orang tua didominasi antara lain oleh kekhawatiran makin merebaknya konsumsi minuman keras, perokok remaja, kebiasaan begadang, pawai sepeda motor, memudarnya sopan-santun anak muda kepada individu yang lebih senior, dan kebiasaan begadang. Muncul definisi baru yang menempatkan "kita" pada posisi yang berhadapan dengan "mereka". "Kita" diidentikkan oleh pribadi/kelompok yang teratur, tertib, saleh, rajin, sukses, sopan, dan sejumlah citra positif lain. Pada "mereka" dilekatkan label, antara lain, gagal, urakan, sumber masalah, pemabuk, kasar, dan atribut negatif lain yang bertolak belakang dengan yang pertama.

Secara simultan, berkembang ketidakpercayaan kepada sekolah-sekolah milik pemerintah. Sekolah semacam ini digambarkan sebagai heterogen dan cenderung banyak diisi oleh "anak-anak nakal" yang dididik dengan standar etika dan norma yang rendah. Kemampuan anak untuk menyaring dan menangkal pengaruh-pengaruh negatif cenderung disepelekan. Tiadanya seleksi masuk, biaya yang murah, terlalu longgarnya penegakan disiplin, dan dekatnya lokasi sekolah dengan 
pasar, terminal, dan pusat keramaian lain adalah hal-hal yang dianggap menciptakan iklim belajar yang buruk bagi siswa. Sekolah negeri juga digambarkan memiliki sistem sanitasi yang buruk, kakus yang jorok, tempat jajan yang tidak higienis, dan sangat permisif dengan kehadiran pedagang keliling yang tidak memahami standar kualitas dan kandungan nutrisi dalam makanan. Dikhawatirkan sejumlah penyakit akibat bakteri akan mudah menjangkiti anak-anak yang sekolah di sana.

Kekuatan-kekuatan eksternal tersebut digambarkan terlalu besar dan kuat untuk dikendalikan. Respons atas situasi tersebut adalah mengisolasi diri dan memperkuat semacam sistem kekebalan bagi anak-anak. Isolasi diri dilakukan dengan memisahkan anak dari lingkungan pergaulan sebaya di permukiman tempat mereka tinggal. Bila ancaman atas keamanan diri dan properti ditanggulangi dengan membangun pagar rumah yang tinggi, memasang teralis logam di jendela dan celahcelah yang berpotensi diterobos pihak lain, dan menginstalasi sistem alarm dan kamera pengawas, maka ancaman pengaruh negatif dilawan dengan menempatkan anak-anak di lingkungan yang dianggap diyakini steril. Termasuk di antara lingkungan steril tersebut adalah sekolah swasta yang dianggap lebih maju, baik karena kurikulumnya, sistem pembelajarannya, maupun karena asumsi lebih tingginya kualitas lulusannya dibandingkan dengan sekolahsekolah lain. Di sekolah-sekolah semacam ini, anak tidak sekedar terpisah dari teman sebaya di tempat tinggalnya, namun juga mendapatkan atmosfer belajar dan bermain yang berbeda serta dididik untuk menyerap nilai-nilai ter- tentu yang cenderung berbeda dengan yang dianut oleh kebanyakan keluarga di sekitar tempat tinggal mereka. Anak diharapkan akan tumbuh menjadi bagian dari "kita" yang berbeda dengan "mereka.

Penguatan sistem kekebalan ditempuh dengan membekali anak-anak dengan hal-hal yang diyakini positif dan membuat mereka sangat sibuk sehingga tidak sempat memikirkan dan menyerap hal-hal negatif yang berasal dari tiga sumber masalah di atas (teknologi informasi, televisi, dan lingkungan tempat tinggal). Pengaruh negatif dianggap akan terkikis, bahkan bisa hilang, oleh kegiatan-kegiatan yang cenderung serius, antara lain mengerjakan tugas-tugas sekolah, menghafal ayat-ayat suci, melaksanakan ritual ibadah secara rutin dan pada porsi yang dari hari ke hari semakin meningkat. Dalam studi risiko kebencanaan, hal-hal tersebut mendekati ilustrasi konsep strategi preventif (Wisner et al. 2007) dan ketahanan diri (Bohle 2007).

\section{Lahir, Berkembang, dan Mapannya Wacana Dominan}

Kekhawatiran orang tua terhadap datangnya nasib buruk kepada diri anak adalah luaran dari proses belajar yang dijalani sejak dikandungnya anak pertama. Untuk memahaminya, perlu pendalaman terhadap proses dan identifikasi terhadap aktor yang terlibat dalam berkembang dan diyakininya suatu wacana dominan. Berbagai buku dan bacaan populer tentang cara mengasuh anak sejak di dalam kandungan beredar luas. Tayangan iklan susu formula, suplemen, dan vitamin di televisi secara berulang menampilkan sosok orang tua 
(diwakili ibu -sic) dengan raut muka dan gerak tubuh yang menampilkan kebahagiaan bersama dengan kehadiran anak yang ditampilkan sebagai individu yang cerdas dan ceria. Banyak pelatihan dan seminar tentang cara menjadi orang tua diselenggarakan. Kini, media sosial menjadi sarana paling banyak dipakai para ibu dan calon ibu untuk saling bertukar kiat dan nasihat tentang cara mendidik anak. Sebagian dari temuan dalam riset-riset psikologi disimplifikasi dan dikemas dengan bahasa yang lebih mudah dimengerti oleh khalayak di luar ranah saintifik, yang kemudian menjadi psikologi populer. Termasuk di dalamnya adalah yang terkenal dengan sebutan parenting.

Aktor yang terlibat dalam pembentukan wacana adalah kerabat, teman seperkumpulan, teman sepergaulan, dan teman kerja. Kerabat mempengaruhi dengan menyampaikan sejumlah capaian dalam hidup yang diraih oleh anggota-anggota keluarga besar, antara lain prestasi akademik, karir, kedudukan sosial, dan "nama besar" keluarga. Setiap anggota keluarga diberikan beban untuk mempertahankan, bahkan meningkatkan semua itu. Kegagalan adalah suatu aib, tidak hanya bagi individu dan keluarga inti, namun juga bagi keluarga besar. Kerabat memberikan arahan agar jalur yang ditempuh sudah tepat dan kendala untuk mencapai target-target tersebut dapat dieliminasi.

Orang tua cenderung memilih membangun jejaring sosial dengan orang-orang yang relatif homogen. Disebut relatif karena tidak ada kriteria dan indikator yang dapat digeneralisasi. Subjektivitas dalam memilih individuindividu yang dimasukkan ke dalam jejaring lebih dominan. Awalnya mereka berkumpul karena adanya kesamaan, misalnya sebagai orang tua murid di suatu kelas atau sekolah tertentu, kesamaan hobi dan minat, keanggotaan dalam suatu perkumpulan, atau alumni dari suatu lembaga pendidikan formal. Terbentuk beberapa lingkaran pergaulan tempat para orang tua berinteraksi. Keanggotaan di dalam lingkaran-lingkaran pergaulan tersebut sebagian di antaranya saling beririsan. Di dalamnya, sejumlah perbincangan mulai dari keluarga, anak, masyarakat, sekolah, sampai dengan halhal praktis yang menyangkut kegiatan seharihari berlangsung. Mereka mendapatkan informasi dan wawasan dari sumber lain, lalu membaginya dengan sesama anggota di dalam lingkaran-lingkaran tersebut. Daya pengaruh setiap individu tidak setara. Anggota yang memiliki pendidikan formal yang tinggi, sukses dalam berkarir, kehidupan ekonomi yang baik, rumah tangga yang harmonis, dan anak-anak yang berprestasi dan berakkhak baik berpotensi menjadi pemberi pengaruh yang lebih besar dibandingkan dengan anggota yang lain.

\section{Kesimpulan}

Nilai dan cara pengasuhan adalah konsekuensi dari berjalannya moda produksi dominan di dalam masyarakat. Pada masyarakat agraris, anak adalah asset berharga keluarga dalam kaitan dengan ketersediaan tenaga kerja untuk aktivitas produksi pertanian. Pada masyarakat industri, anak cenderung dinilai negatif. Semakin mengendurnya ikatan keluarga inti dari keluarga besar menyebabkan beban pengasuhan anak semakin cenderung dibebankan kepada orang tua mereka. Anak menjadi beban finansial dan psikologis. 
Masyarakat informasi ditopang oleh lalu lintas dan kontestasi gagasan melalui beragam media. Tingkat kecepatan infomasi dan derajat pengakuan yang diterima oleh agensi dipengaruhi oleh teknologi dan otoritas pembawanya. Wawasan, gagasan, dan nasihat yang dibawa beberapa anggota cenderung lebih kuat dalam menciptakan wacana dominan di tengah-tengah suatu kelompok.

Kesimpulan yang dihasilkan oleh penelitian ini adalah: Pertama, proses transisi dari masyarakat agraris menuju kepada masyarakat industri dan masyarakat informasi melahirkan kekhawatiran di kalangan orang tua. Sumber kekhawatiran adalah media, masyarakat sekitar, dan lingkungan pergaulan teman sebaya anak-anak. Rasa takut ini diiringi oleh lunturnya kepercayaan kepada lembaga-lembaga pendidikan formal milik negara yang cenderung dipersepsikan sebagai pembawa pemikiran dan kebiasaan sekuler.

Kedua, ketakutan-ketakutan tersebut terbentuk melalui proses tercipta, berkembang, dan termapankannya wacana. Ada media dan ruang-ruang interaksi yang di dalamnya didominasi oleh beberapa individu yang diyakini memiliki otoritas untuk memahami, menjelaskan, mengajarkan, dan mempraktikkan sejumlah pemikiran dan cara hidup yang ideal bagi anak-anak pada masa kini.[]

\section{Daftar Pustaka}

Ainsworth, James, ed. 2013. Sociology of Education: an A-to-Z guide, Volume 1. Los Angeles: Sage Reference.
Asadullah, M. Niaz. 2018. "Madrasah for Girls and Private School for Boys? The Determinants of School Type Choice in Rural and Urban Indonesia." International Journal of Educational Development 62(November 2017):96-111.

Binelli, Chiara dan Marta Rubio-Codina. 2013. "The Returns to Private Education: Evidence from Mexico." Economics of Education Review 36:198-215.

Bohle, Hans-georg. 2007. "Geographien von Verwundbarkeit." Geographische Rundschau 2001:20-25.

Coleman, James S. dan Thomas J. Fararo. 1992. "Introduction." dalam Rational Choice Theory: Advocacy and Critique, ed. J. S. Coleman dan T. J. Fararo. Newbury Park: Sage Publications.

Douglas, Mary. 1992. Risk and Blame: Essays in Cultural Theory. London: Routledge.

Giddens, Anthony. 1990. Consquences of Modernity. London: Polity Press.

Heyns, Barbara. 1996. "This Little School Went to Market: Private Schooling in PostCommunist Poland." dalam James $S$ Coleman, ed. J. Clark. London: Routledge Falmer.

Hodgetts, Darrin dan Kerry Chamberlain. 2014. "Analysing News Media." dalam The Sage Handbook of Qualitative Data Analysis, ed. U. Flick. Sage Publications.

Jacob, W. James dan Juhnan Ma. 2013. "Australia." dalam Sociology of Education: an A-to-Z Guide. Volume I, ed. J. Ainsworth. Los Angeles: Sage Reference.

Kemendikbud. 2016. Perbandingan Jumlah Sekolah Negeri dan Swasta. Jakarta.

Longfield, David dan James Tooley. 2017. "School Choice and Parental Preferences in a Poor Area of Monrovia." Inter- 
national Journal of Educational Development 53:117-27.

Mandic, Sandra et al. 2017. "Enrolling in the Closest School or Not? Implications of school choice decisions for active transport to school." Journal of Transport \& Health 6(March):347-57.

Mariel, Petr, Riccardo Scarpa, dan Ainhoa Vega-bayo. 2018. "Joint Parental School Choice: Exploring the Influence of individual preferences of husbands and wives." Regional Science and Urban Economics 68(February 2017):23-35.

Rapley, Tim. 2014. "Sampling Strategies in Qualitative Research." Hal. 49-63 in The Sage Handbook of Qualitative Data Analysis, diedit oleh U. Flick. Los Angeles: Sage Publications.

Rosen, Lisa. 2003. "The Politics of Identity and the Marketization of U.S. Schools: How Local Meanings Mediate Global Struggles." dalam Local Meanings, Global Schooling: Anthropology and World Culture Theory, diedit oleh K. M. Anderson-Levitt. New York: Palgrave Macmillan.

Sciortino, Rosalia dan Ines Smyth. 2002. "Mitos tentang Keselarasan: Kekerasan Rumah Tangga di Jawa." dalam Order Zonder Order: Kekerasan dan Dendam di Indonesia 1965 - 1998, ed. F. Husken dan H. de Jong. Yogyakarta: LKiS.

Scott, Alan. 2000. "Risk Society or Angst society? : Two Views of Risk, Consciousness and Community." dalam The Risk Society and Beyond: Critical Issues for Social Theory, ed. B. Adam, U. Beck, dan J. Loon. London: Sage Publications.
Sorensen, Aage B. 1996. "Educational Opportunities and School Effects." dalam James $S$ Coleman, ed. J. Clark. London: Routledge Falmer.

Tangdilintin, Paulus. 2004. "Sekilas Perkembangan Kajian Keluarga Perkotaan." dalam Bunga Rampai Sosiologi Keluarga, ed. T. Ihromi. Jakarta: Yayasan Obor Indonesia.

Vellos, Renira E. 2013. "General Typology: Alternative Schools and Programs." dalam Sociology of Education : an A -to-Z Guide. Volume I, ed. J. Ainsworth. Los Angeles: Sage Reference.

Williams, Trevor dan Peter Carpenter. 1991. "Private Schooling and Public Achievement in Australia." International Journal of Educational Research 15(5):411-31.

Willig, Carla. 2014. "Interpretation and Analysis." pp. 136-50 in The Sage Handbook of Qualitative Data Analysis, diedit oleh U. Flick. Los Angeles: Sage Publications.

Wisner, Ben, Piers Blaikie, Terry Cannon, dan Ian Davis. 2007. At Risk. London: Routledge.

Yaacob, Noor Alyani, Mariana Mohamed Osman, dan Syahirah Bachok. 2014. "Factors Influencing Parents' Decision in Choosing Private Schools." pp. 242-53 dalam AMER International Conference on Quality of Life, vol. 153. Kota Kinabalu: Elsevier B.V. 